\title{
Introduction: governance of innovation in emerging countries: understanding failures and exploring options Stefan Kuhlmann and Gonzalo Ordóñez-Matamoros ${ }^{1}$
}

\section{INTRODUCTION}

In a historical United Nations (UN) conference held in 2000, the leaders of 189 countries agreed upon a set of eight major ambitious development goals (called the 'Millennium Development Goals' - MDGs) to be attained by December 2015 to reduce extreme poverty, hunger, illiteracy and disease. ${ }^{2}$ The 'deadline' came, and many of the targets set were, as expected by many, not met for a large number of countries. ${ }^{3}$

Part of the agreed-upon 'recipe' at the time of the declaration was for governments to design and implement knowledge, science, technology and innovation policies to facilitate progress via investment, monitoring of research and development (R\&D), and knowledge and technology transfers to boost progress (UN 2005). This was based on the assumption that, inter alia, these activities increase productivity via process innovation, create markets via product innovation, protect jobs, reduce the consequences of extreme poverty, prevent and treat local diseases, and contain and reverse the continuing loss of environmental resources among other problems affecting well-being in emerging countries.

Since the 2000 UN MDG declaration took place, the bestperforming emerging countries in terms of $R \& D$ investment have substantially improved their innovative capacity as measured by traditional indicators such as the number of patents and scientific publications, but high rates of extreme poverty continue, and inequality and social exclusion are increasing (Piketty 2014). In many countries fragmentation persists, gender and race/caste inequalities are lasting, and the lack of access to basic public services remains a common problem. As a report from the OECD claims, 'In emerging economies ... a sustained period of strong economic growth has helped lift millions of 
people out of absolute poverty. But the benefits of growth have not been evenly distributed and high levels of income inequality have risen further. ${ }^{4}$ Considering the BRICS countries (i.e. Brazil, Russia, India, China and South Africa), for example, historical legacies remain dominant, such as sharp class disparities in Brazil, vulnerability of families with children in Russia, malnutrition in India, the rural-urban divide in China, and high unemployment rates in South Africa (Scerri and Lastres 2013).

Recently, and as replacement for the 'expired' UN MDGs, a new set of ambitious targets has been set around the so-called 17 'Sustainable Development Goals' (SDGs) on which new challenges have been agreed upon in the framework of the UN. ${ }^{5}$ An obvious question is what can innovation policies do to help those countries get closer to achieving them?

Focusing on innovation governance ${ }^{6}$ and public policies in emerging countries, this book aims to understand related governance failures and to explore options for alternative, more efficient approaches. We build on earlier work with a long track record of research and innovation policy in emerging countries. This includes work done by Bengt-Âke Lundvall, Carlota Perez, Chris Freeman, Daniele Archibugi, Francisco Sagasti, José Cassiolato, K.J. Joseph, Mammo Muchie, Renato Dagnino and Susan Cozzens and the work of some of the contributors in this book including Abdelkader Djeflat, Adesina Ayobami Oyewale, Cristina Chaminade, Gabriela Dutrénit, Gillian M. Marcelle, Hernán Thomas, Judith Sutz, Mario Scerri, Rodrigo Arocena and Sunil Mani, among others. Our take on innovation policy in this book, however, brings a new perspective, as it focuses on governance issues resulting from the interplay between policy, theory and practice to better understand failures and opportunities in those countries.

To start, let us first acknowledge that there are different perspectives on the role of innovation policies for development, understood as a basic layer of framing conditions. Then, a more systematic discussion is offered on the possible causes explaining the lack of progress on the use of innovation for development as a key governance challenge in poor countries. Last, we identify new options and emerging opportunities for change taking place at conceptual and policy levels. 


\section{Diverging Perspectives}

Heated political debates about the specific role of innovation policies in providing the conditions for development have taken place in three different and opposing directions. In one direction, a 'conservative view' sees innovation policies implemented in emerging countries as simply ineffective and insufficient given 'structural problems', where concerns about basic needs such as access to drinkable water, health services, electricity, primary education, infrastructure for mobility and production, employment and safety should keep governments and firms occupied and away from investing large and continued amounts of resources on innovation activities originated locally. ${ }^{7}$ As evidence of this view, very few of these countries invest more than 2 per cent of their GDP on science, technology and innovation (STI) activities. From this perspective, countries would progress through small, incremental changes, rather than through risky and 'luxurious' innovation activities.

Second, a more 'progressive view' is also found in current political debates, where the only way to get out of the 'poverty trap' resulting from the former view is by investing heavily in $R \& D$ and technological innovation, which has to be done through designing policies targeting the academic and entrepreneurial 'elite', as they are perceived to be the ones able to bring about progress for all; South Korea often serves as an example (e.g. Lee 2000; Archibugi and Pietrobelli 2003). This is progressive in the sense that it contrasts with the aforementioned naturalistic view, but remains partly conservative in the sense that it focuses on the role of a few elite actors.

A third perspective, like the progressive view, focuses on innovation policies, but transcends it by portraying a 'radical view', which sees creativity, resourcefulness, local capabilities, indigenous knowledge, social innovation and innovation for social inclusion as the main policy goals governments in emerging countries should focus on in order to overcome the aforementioned poverty trap. From this point of view, it is very important to promote scientific research and the development of cutting-edge technology, but it is perhaps even more important to promote learning and problem-solving capabilities at the individual, community and institutional levels, where the leadership is not to be left to the top of the social pyramid but to grow from the bottom with government support. From this 
perspective, knowledge, science, technology and innovation (innovation policies) should be revised and inspired by the appropriate models to effectively address the right public problems while avoiding the implementation of programmes too narrowly defined, too poorly managed and badly implemented. From this perspective, money is not the problem, but the lack of ideas, leadership and political will to embrace all sectors of society in the design and implementation of such policies is to be blamed.

This book could be positioned as an academic effort to shed light on the debates held around the second and third perspectives. In fact, for the most part, the chapters of this book follow a rather normative stance (at least implicitly) in the sense that the authors claim that something can and should be done differently in emerging countries in order to change current trends and conditions. In the process, this book provides debates and evidence of both barriers and opportunities for change, and more precisely attempts to contribute to:

a. a better understanding of the reasons why in many cases knowledge, science, technology and innovation activities are not satisfactorily contributing to the expected progress at the desired pace in those countries, which can perhaps be attributed to governance and policy issues and to barriers which can be found in theoretical failures, governance failures and social capital failures; and

b. a better understanding of emerging developments, opportunities and options taking place in terms of innovation theory, policy and practice in emerging countries, which could be judged more relevant and as having the potential to better orient local capabilities to make effective contributions to the relatively old and elusive quest for development.

Indeed, a basic claim inspiring this book is the need for a better understanding of options for change, leading hopefully in the desired direction in those countries sharing similar types of problems, where more relevant and effective public policies are needed to better profit from what innovation (available or, preferably, to be developed) could offer to improve the quality of life. Fundamental questions need to be asked to better draw the 'big picture' of the overarching puzzle characterizing the challenges these countries typically face, and to point to the roles both their 
academic and their policy domains would have to play to shape the future of these countries.

In contribution to the first goal, that is, to better understand why innovation-related governance is not contributing satisfactorily to local progress in emerging countries, the chapters of the book offer discussions about, inter alia, the main dilemmas these countries typically encounter, by: a) providing an examination of the underlying assumptions supporting innovation policies (Delvenne and Thoreau, Chapter 1; Marcelle, Chapter 2; Rennkamp, Chapter 3; Scerri, Chapter 4; Djeflat, Chapter 5); b) looking at key features of innovation policy-making processes (Chaminade and Padilla-Pérez, Chapter 6; Dutrénit and Puchet, Chapter 7; Salazar, Chapter 8; Loconto and Simbua, Chapter 9; Mani, Chapter 11; Oyewale et al., Chapter 12); c) identifying typical innovation governance challenges in the framework of poverty and globalization (Dutrénit and Puchet, Chapter 7; Salazar, Chapter 8; Loconto and Simbua, Chapter 9; Orozco, Chapter 10; Oyewale et al., Chapter 12); d) analysing the contextual determinants of innovation policy change, failure or effectiveness in these countries by examining the role of cultural, historical or political drivers, barriers, policies and governance issues (all the chapters in this book in one way or another); e) studying the role of indigenous knowledge (Delvenne and Thoreau, Chapter 1; Marcelle, Chapter 2; Rennkamp, Chapter 3; Scerri, Chapter 4; Djeflat, Chapter 5; Loconto and Simbua, Chapter 9; Orozco, Chapter 10; Mani, Chapter 11; Oyewale et al., Chapter 12; Voeten, Chapter 14; Catalán, Chapter 15; Thomas et al., Chapter 17); f) scrutinizing the role of international aid, cooperation, funding organizations, NGOs, multinational corporations, universities, networks and/or media (Delvenne and Thoreau, Chapter 1; Marcelle, Chapter 2; Rennkamp, Chapter 3; Loconto and Simbua, Chapter 9; Arocena and Sutz, Chapter 13; Robles-Belmont and Vinck, Chapter 16); g) studying the role of local management, leadership capabilities and entrepreneurship (Marcelle, Chapter 2; Djeflat, Chapter 5; Orozco, Chapter 10; Mani, Chapter 11; Oyewale et al., Chapter 12; Voeten, Chapter 14; Catalán, Chapter 15; Thomas et al., Chapter 17); h) studying the role of organizations, institutions, norms and values (Marcelle, Chapter 2; Chaminade and Padilla-Pérez, Chapter 6; Dutrénit and Puchet, Chapter 7; Salazar, Chapter 8; Arocena and Sutz, Chapter 13; Voeten, Chapter 14; Catalán, Chapter 15; RoblesBelmont and Vinck, Chapter 16); and i) considering the role of 
corruption and/or ideology, among other aspects potentially affecting innovation in emerging countries.

As for the second overarching goal, that is, to better understand and highlight novel options and opportunities for innovation theory, policy and practice taking place in emerging countries with the potential to positively impact development processes, the chapters provide evidence of good practices which can be classified as alternatives to current approaches. These include the revision of experiences falling into categories such as grassroots innovation, social innovation, social technologies, innovation for inclusion and so on (Arocena and Sutz, Chapter 13; Voeten, Chapter 14; Thomas et al., Chapter 17), as well as new ways of governance (Chaminade and Padilla-Pérez, Chapter 6; Dutrénit and Puchet, Chapter 7; Catalán, Chapter 15; Robles-Belmont and Vinck, Chapter 16).

\section{A Balanced Analysis of Failures and Opportunities}

Although the analyses of the topics mentioned are not done in a systematic way, and in some cases the claims cannot be supported by empirical evidence (the lack of information is indeed part of the problem), specific reflections on the problems referred to are discussed based on the experience, knowledge and understanding of the authors regarding the nuances characterizing these countries, where some causes of the problem investigated can be understood in light of one or a combination of what could be called sources of 'systemic failures' (Woolthuis et al. 2005; Brown et al. 2015).

Indeed, by studying failures, the editors of this book claim that one can better understand current conditions in emerging countries as well as better identify opportunities for improvement in terms of innovation policies in those countries (Muchie et al. 2003). However, contrary to a rather one-side-of-the-story view highlighting either a traditional positivistic and successstory perspective or a sole critical and pessimistic perspective highlighting bottlenecks that keep innovation activities from effectively addressing long-standing problems in emerging countries, the chapters of this book show two sides of the same coin: challenges and opportunities of innovation policies emerging countries typically face.

As for the failures discussed, related to the difficulties and futures these countries (may) face, we clustered them as 
'theoretical failures', 'governance failures' and 'social capital failures'. These are discussed in detail and more systematically later in this chapter. Regarding the opportunities identified, there are good reasons to believe that many of the countries belonging to the umbrella concept of developing countries have the resources and leadership required to solve many of their current socio-economic and governance problems based on the promises of innovation and the associated policies designed and implemented. What happens in some of these countries can serve and in fact has served to overcome many such problems and can even serve as models of success from which the developed countries can also learn. We make this claim considering the rapid evolution and constant change of conditions, which makes every country developing or emerging at some point, surrounded by complex and hard-to-understand and -address problems. ${ }^{8}$

\section{The Dance Metaphor as Heuristic to Identify Both Failures and Options}

Kuhlmann et al. (2010) proposed a heuristic depicted as the 'innovation policy dance metaphor' to better understand innovation practice, policy and theory (IPT) trajectories and their interplay. By so doing, the authors focus on the articulation (or lack thereof) between the three main 'dancers' of IPT. Hence, from a systemic and evolutionary perspective the authors claim that ideas, rationales and instruments of innovation policy emerge as a result of interactive learning among actors involved in innovation practice, innovation-related public intervention strategies, and innovation research and theory, where mutual learning through interacting with these three dancers constantly creates and changes IPT configurations.

Thanks to this heuristic, it is possible to identify situations where sometimes innovation practice is the driving force in a configuration, sometimes theory, sometimes public or private policy. It also helps to identify when the dancers may happen to bump into each other or may enjoy phases of pure harmony (see Figure I.1).

The metaphor helps to explain IPT configurations in emerging countries and helps us to better understand the multiple failures that co-exist in those countries, which explain in part why innovations are not effectively contributing to their development, as well as the emergence of new options for development 


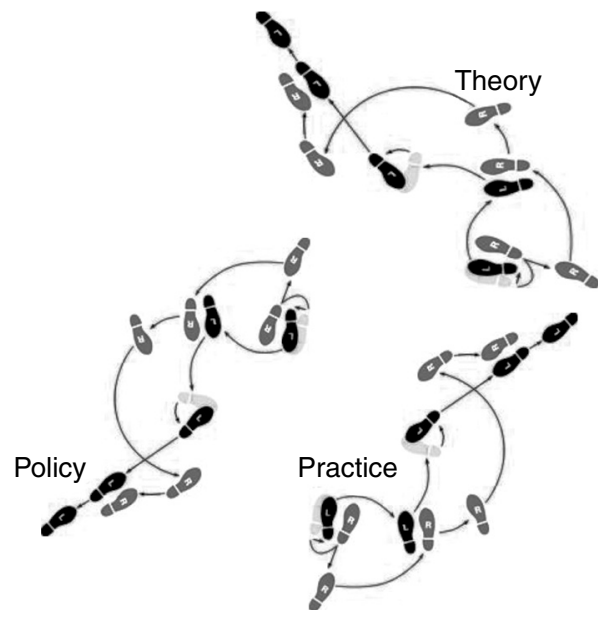

Source: Kuhlmann et al. (2010).

Figure I.1 Innovation policy dance: a systemic and evolutionary perspective

based on innovation. In fact, we find this metaphor an instrumentally valuable device for the purpose of assessing the rationales and relevance of innovation policy in emerging countries. Furthermore, it helps not only to identify the main rationales behind innovation policies, practices and theories applied in those countries, but also to identify the lack of relevance whenever there are mismatches or 'bumps' between the dancing partners, that is, when policies do not respond coherently to relevant theories, when theories do not respond to (or reflect) relevant practices, and when practices do not respond to relevant policies, and vice versa.

Moreover, the metaphor also helps to identify specificities and key characteristics emerging country systems share and, more importantly, to assess assumptions related to how theory, policy and practice in those countries interact and/or are often taken for granted by both scholars and policy makers, therefore leading to overlooking important causes of failure. Finally, the heuristic can help to identify and help us understand the emergence of new options for development based on innovation activities, theories and policies as experienced recently in emerging countries.

The innovation policy dance metaphor therefore identifies 
three different types of dancers: a) innovation (policy) researchers and scholars; b) government agencies and public authorities; and c) creative people, entrepreneurs and innovators. The first type of dancer strives for understanding and creating original ideas. The second has substantive goals like security, quality of life, sustainability and so on, under which a variety of actions are implemented. Finally, innovation-producing actors such as firms, grassroots innovators, civil society organizations, social innovators, frugal innovators and individual entrepreneurs at large think in terms of survival, market success or strategic advantages, where individual researchers look for reputation and rewards, while NGOs have their own goals to pursue or influence (e.g. health improvement, clean environment, etc.). These sets of actors are not homogeneous, as tensions and conflicts exist among them and change over time, where sometimes these differences involve conflicting paradigms, schools of thought or ideologies, power struggles, compromises, and a variety of resources, capabilities, activities and strategies.

In this chapter, we first analyse some hypotheses as to why innovation-related governance efforts do not contribute to progress in emerging countries as an expected key goal of governments. This is done by looking at the IPT dance configurations observed related to the role of theory, and in particular looking at the relationships between theory and policy and between theory and practice and the existing gaps or dancing outcomes (blocking bumps) in such configurations in emerging countries.

This debate is then followed by an analysis of the factors related to what can be called governance failure, briefly focusing on innovation governance capabilities, and in particular on the role of policy and its interaction (relevance, response) with innovation practice. In so doing, we refer to: factors related to the local institutional capabilities to produce, promote, disseminate and use innovation; institutional capacities to set, design and evaluate innovation activities and policies; institutional capacities to interact for delivering and governing innovation while avoiding institutional proliferation and duplicity in terms of roles and functions; risks of institutional capture by political interests and patrons; political will; and corruption.

Then, we briefly discuss factors related to (lack of) productivity and entrepreneurship, as well as to the enabling and hindering conditions characterizing innovation practice in those countries. 
It is important to highlight that the factors discussed do not operate independently, as in many cases a factor helps to explain the presence of another factor. In practice, the presence of only one factor could be sufficient to cause failures in the entire innovation system, and therefore prevent these activities from contributing effectively to progress in the countries concerned.

After that, we analyse the emergence and rationales of new options for better profiting from innovation activities and facing short-term as well as long-term challenges in emerging countries through implementing more relevant policies and programmes.

\section{BUMPY DANCING AND STORIES OF SYSTEMIC FAILURES}

\section{Theoretical Failures: Theory as the Leading Dancing Partner}

Public policies and social or business practices of innovation are more often than not inspired by models, theories, paradigms, approaches, frameworks, concepts or assumptions. These sources of ideas can be categorized as irrelevant when they are designed assuming contexts that do not match the application scenario, and therefore lead to ignoring (or rejecting) local reality. Also, as happens very often, they can be categorized as misleading, as policies and practices are inspired by models or theories that may be interpreted in such a way that can lead to the same consequence of ignoring important elements of the context owing to a lack of knowledge or understanding, resources or political will. ${ }^{9}$

Economic growth, for example, as explained by orthodox theorists, has been found to be an insufficient condition for emerging countries to overcome persistent poverty and social inequality. Furthermore, even in the case of rapidly emerging countries such as the BRICS, most science, technology and innovation policies are aimed at achieving economic growth and competitiveness, not at reducing poverty or inequalities, where spending substantial investment in such activities has rarely benefited the poor.

Other examples of theoretical or conceptual failures that can be claimed to have resulted in the wrong design and/or implementation of policies aiming at encouraging the production or use of innovation in these countries include: 
- Theories related to the role assigned to innovation in development. Neoclassical economics tends to assign a marginal or external role to innovation as a factor explaining development. This explains in part the traditional lack of interest by governments in those countries towards innovation activities. As said before, even when it is considered it is seen as relevant for increasing growth and competitiveness more than cohesion, opportunity creation and wellbeing, which according to the dominant belief should result almost automatically from growth-led strategies.

- Theories related to the role assigned to governments and markets. Neoliberal schools of thought claim that markets should govern or rule actors' behaviour and governments should play a rather low-profile role, only intervening to allow markets to operate freely and efficiently. This leads again to a scenario of underinvestment in innovation activities when left to the market alone.

- Perceived main innovation policy challenges as encouraging excellence rather than relevance of $R \& D$, leading to innovation activities being irresponsive to the majority's needs.

- The demarcation criteria for 'good' and 'bad' innovation performance. It is commonly thought that one of the main outcomes of innovation systems should be patents and publication in highly ranked journals (in English) rather than on popularizing, disseminating or encouraging knowledge production among local peers or users.

Furthermore, theoretical shortcomings involve situations in which the models are copied, a very common practice in emerging countries that experts call 'isomorphism', well or poorly interpreted, and which if combined with inaccurate design or biased interpretation lead to policies, programmes and projects that not only do not contribute to solve the problems that motivated their application, but that possibly generate new problems. ${ }^{10}$

The chapters by Delvenne and Thoreau (Chapter 1), Marcelle (Chapter 2), Rennkamp (Chapter 3), Scerri (Chapter 4) and Djeflat (Chapter 5) offer a detailed discussion of how the systems have been acutely affected by uncritically applying theoretical frameworks that were designed for other realities (such as those operating in OECD countries). 
Examples of potential theoretical failures that can be blamed for misleading innovation policy and therefore generating harmful effects (e.g. opportunity costs) in emerging countries have to do with the assumptions underlying models, such as:

- the so-called OECD Oslo Manual's definition of 'innovation' (OECD 1997), ${ }^{11}$ which by focusing on or valuing what is 'new to the world' tends to undermine non-world-class and localized innovation efforts;

- the OECD Frascati Manual's ${ }^{12}$ definition of 'research', which by highlighting the importance of producing knowledge based on the scientific method tends to imply that the only knowledge source of value from the academic enterprise comes from research and downplays other sources of knowledge production which could also be of high value;

- the 'linear model of innovation', also called 'Vannevar Bush's model' (Mowery 1997), which assumes that the innovation process is explained as a relatively straight line with a clearly delineated progression from basic research to applied research, demonstration and full-scale development (criticized for being unrealistic by Kline and Rosenberg 1986), and tends to undermine the potential role of non-R\&D efforts and alternative knowledge relevant for innovation and progress;

- the national system of innovation approach (Freeman 1987; Lundvall 1992; Nelson 1993; Edquist 1997), which, by highlighting the importance of different types of actors and roles to explain how innovation results, tends to be taken as a normative framework, leading to undermining institutional learning and evolutionary processes and determinants (Oteiza 1992; Arocena and Sutz 2001; Dagnino and Thomas 2001; Viotti 2002; Arocena and Sutz 2003, 2006; Hurtado and Mallo 2012), which could furthermore lead to an unhistorical understanding of innovation as an outcome (Perez 2012), or result in oversimplification of the role of R\&D and the importance for capacity building at the local, sub-national and regional levels (Acs et al. 1996; Cooke et al. 1997; Acs 2000), as well as at the sectoral level (Carlsson and Jacobsson 1994; Malerba 2002);

- the Triple Helix model (Etzkowitz and Leydesdorff 2000; Leydesdorff 2000), which by depicting knowledge as the result of joint ventures between university, industry and 
government actors also tends to be taken as a normative model in emerging countries, leading potentially to extreme cases of commercialization or privatization of knowledge produced at public universities in those countries;

- the 'Mode 2' model of knowledge production (Gibbons et al. 1994), which portrays research and innovation as a result of multi-disciplinary, multi-sectoral and problem-oriented research, and again tends to be taken as a normative model, possibly undermining the role of autonomous universities and of basic research in emerging countries;

- the technology transfer paradigm (Bozeman 2000), which, by implying that in order for emerging countries to catch up they should invest more on adopting and adapting technologies already produced elsewhere than on developing their own, could contribute to the increase of their dependency and extend their lagging condition;

- the 'publish or perish' paradigm (McGrail et al. 2006), which claims that the main mission of academics is to produce articles in journals with high impact factors (in Web of Science or in Scopus), tending to undermine the quality of education and outreach, as well as the relevant contribution of academics to the countries;

- the international research collaboration paradigm (Luukkonen et al. 1992), which, by claiming that, in order to modernize local research and knowledge production, local research teams need to connect with prestigious research teams globally, probably leads to underestimating the potential of local capabilities;

- the import substitution model (Perez 1996; Silva 2007), which, by claiming the importance of strengthening local capabilities by preferring local production, may have led to undermining the value of foreign knowledge and technology as important sources of modernization;

- the neoliberal and 'laissez-faire' approach to markets (Palley 2005), which, by claiming that local governments do a better job by not intervening, tends to undermine the key role of public policies to overcome market or systemic failures, or to create local markets and improve absorptive capacity and STI capabilities.

There may be more examples like those listed, but in light of the local realities in emerging countries they may appear to 
be based on fictions or inaccuracies that by becoming normative models may lead or have led to Type Three Errors (i.e. solving the wrong problem). The harmful effect resulting from the uncritical application of such models is related to the fact that they constitute sources of distraction for policy and practice, causing high opportunity costs by diverting focus away from the real (and perhaps more pressing but less organized and therefore recognized) problems, and avoiding the implementation of innovation policies and practices more adjusted to local needs, capabilities and realities.

Of course these models are often fuelled by ideologies based on the uncritical belief that growth inevitably generates development, thus inspiring the design and implementation of innovation public policies and practices that can in fact be both irrelevant, not taking into account emerging countries' needs and capabilities and, more importantly, naive, not considering emerging countries' specificities and political and institutional contexts. For many, policies that favour the accumulation of resources and the exclusion of large portions of society rather than focusing on the creation or distribution of opportunities are to be found among those causing the worst systems failures. Similar claims are made regarding policies that focus on the production of world-class science or innovations novel to the world instead of prioritizing on products of knowledge and science that respond to local demands and values as preconditions to developing sustained growth and development. Several chapters in this book make some of these claims. Indeed, such models have led to the design and implementation of public policies and entrepreneurial practices that ignore or undermine the role and potential of local non-technological innovative capabilities (or low or soft technologies), despite being present in relative abundance or in local, community-based or traditional knowledge, therefore leading not only to increased inequality, but unfortunately to the neglect of local needs, where local potential is also wasted.

The story would be very different if innovation policies took into account models better adapted to the realities, that is, based on scarcity rather than on the presence or abundance of resources and that acknowledge the lack of institutional capacities as opposed to taking for granted political will and available knowledge and institutional maturity.

Importantly, the challenge is of course to know where to locate public policies within the implied ideological-political 
spectrum ranging from a reliance on accumulation to a focus on distribution as the main policy goal, because both, taken to the extremes, tend to be harmful where, as implied above, excessive accumulation may lead to inequality, exclusion and high opportunity costs, but excessive distribution can also lead to unsustained growth, loss of competitiveness, high transaction costs and, again, high opportunity costs. This in turn prevents development, thus resulting in a vicious circle.

Finally, a meta-level factor making innovation policies fail in emerging countries has to do with some of the values implicit in religion, tradition or ideology, which may constitute barriers to creativity and to critical thinking, inquiry, reflexivity, scepticism, change and excellence. These are all important determinants of innovation and refer to factors that have a very important relative weight in most emerging countries.

The factors discussed so far also determine the ways governance and social capital failures result and therefore help to explain why taking advantage of knowledge, science, technology and innovation as sources of development is so elusive in emerging countries. We now turn to discussing such factors in the next sections.

\section{Governance Failures: Policy as the Leading Dancing Partner}

Even if the theoretical underpinnings and models do fit the historical, economic and social conditions and if promising social or business practices of innovation are available, satisfactory progress in an emerging country can be spoiled if innovation models and practices are not supported by adequate governance approaches and public policies. Several chapters in this book reveal the following structural conditions leading to governance failures:

- lack of economic, technical and legal resources and basic infrastructure such as formal education, telecommunications, transport, laboratories, research centres and so on, which usually provide a favourable environment for innovation;

- unreliable political institutions, organizations and procedures; corruption; lack of trust in public policy; and political instability, leading to policy interruption;

- governance dominated by social or armed conflicts; 
- low government valuation of knowledge, science, technology and innovation as a theme of a public agenda for development vis-à-vis other relatively more pressing issues with short-term impact;

- governance routines oriented towards supporting extractive economic activities and exploitation of natural resources with low interest in high-added-value products;

- low local institutional and governance capacity to design, implement and evaluate instruments, tools and programmes aimed specifically at promoting knowledge use, adaptation, production, dissemination and innovation, or in general to lead the institutional and cultural changes necessary to make innovation an engine for development.

A common cause of committing Type Three Errors, that is, of solving the wrong problems, is the fact that decision makers frequently act as 'solution advocates' rather than as 'problem advocates'. That is, as Ordóñez-Matamoros et al. (2013) argue, in emerging countries it is extremely common that policy makers implement preferred solutions rather than the appropriate solutions, which causes bias resulting from ignorance or corruption (a variable that is not found in either of the predominant innovation models or theories), or is due to lack of resources. Moreover, part of the reasons explaining why decision makers frequently play the role of solution advocates rather than the role of problem advocates has to do with the absence of spaces for deliberation and citizen participation, as well as a limited capacity of critical analysis and assessment of policies and accountability by different actors, ${ }^{13}$ in other words a lack of strategic intelligence (Kuhlmann et al. 1999).

The consequence of such bias is the design and implementation of irrelevant policies vis-à-vis the potentials and needs of local contexts. The result of this issue is that policies tend to target a narrow spectrum, favouring a minority of the society, leading in turn to the lack of interest, involvement and commitment of the society at large (and, in particular, of potentially innovative small companies and creative communities) in the design and implementation of national strategies focused on making innovation activities long-lasting engines of development and wellbeing. This is perhaps one of the reasons why such policies or programmes often lack the social and political legitimacy needed 
to achieve the desired impacts, as they are perceived, in most cases, as a luxury or foreign to their specific situations.

Allegedly, this has also led to the fact that knowledge and innovation are not valued as factors of production or determinants of well-being, and therefore are not considered in the design of social or business strategies in response to local needs, leading some initiatives to lack market acceptance and to fail, allowing inertia and the status quo to dominate.

In addition to the aforementioned problem, those countries tend to lack organizational and institutional capacities of interrelation and coordination, both horizontally between instances of the same hierarchical level in different sectors and vertically inside a hierarchy in the same sector of activity. The chapters by Chaminade and Padilla-Pérez (Chapter 6) and Salazar (Chapter 8) provide evidence of this failure.

In this context, the absence of communication channels between different centres of decision making and implementation tends to neutralize the effects obtained by efforts made to promote the use or production of knowledge and innovation. Related to this, institutional proliferation results as a product of the political clientelism of the administration on behalf of groups or political parties, as well as from the egos of certain individuals in positions of political power, co-existing sometimes with regional strongholds where interest groups are able to capture the public agenda in ways that may or may not be associated with corruption. The consequence of this state of affairs is duplication, waste or, worse still, the presence of key thematic or sectoral 'orphans', which leads to the persistence of a state of underdevelopment.

This is what a costly governance failure implies, which at least partly explains why knowledge and innovation fail to successfully contribute to progress in emerging countries. Hence, government failure occurs as a consequence of the fact that policy agendas are defined arbitrarily and narrowly without suitable planning, ignoring local capacities, needs and barriers, and following rationales that undermine public goods, where policies are implemented by rather sclerotic institutions lacking leadership, work ethics, resources and capacity to interact and coordinate with other actors.

Hence, the factors discussed so far referring to theoretical as well as governance failures determine the ways some factors explain social capital failures, which also helps to explain why 
taking advantage of knowledge and innovation as sources of development is so difficult in emerging countries (Sagasti 2004). We now turn to discuss briefly such factors related to social capital failures.

\section{Social Capital Failures: Practice as the Leading Dancing Partner}

These types of failures are perhaps the ones we know the least about concerning the reasons why knowledge, innovation and related governance are not contributing enough in emerging countries. In respect of micro- or performance-level failures one can point to a weak entrepreneurial and innovative culture, which implies bad planning capabilities, risk and effort aversion, lack of interest or of trust in associating and undertaking collective initiatives, and low private investment in the production and adoption of knowledge and technologies. These problems can be called 'social capital failure' (Fukuyama 2001), which is said to occur when innovation activities (broadly defined to include creativity and capacity building) are performed and managed in the framework of marginalization, social stigma, distrust in others and in local institutions, short-term vision, informality, and high levels of career uncertainty perceived by scientists, innovators and entrepreneurs in those countries.

Many of these debates take place in the framework of the conferences of the Global Network for Economics of Learning, Innovation, and Competence Building Systems (Globelics), which gather a large network of scholars who, for almost 15 years, have been applying the concept of 'learning, innovation, and competence building' focused on building such systemic capacities in the global South (e.g. Lundvall et al. 2009), while recognizing that there has been some failure in, for example, the understanding of the National Innovation Systems approach as commonly interpreted in the global North, which is seen as misleading emerging countries owing to the aforementioned problems and deficiencies, usually taken for granted by the scholars in developed countries. ${ }^{14}$

So far, we have discussed some of the factors potentially explaining why innovation and related governance have not sufficiently contributed to progress in emerging countries. Other factors not discussed include geopolitical, historical or environmental reasons, for which little information is available. We now 
turn to discussing the opportunities currently opening up in and to emerging countries, which result from experimentations and innovations affecting IPT configurations and with the potential to support their sustained progress.

\section{CREATIVE DANCING AND STORIES OF SUCCESS: MAKING KNOWLEDGE AND INNOVATION AN ENGINE FOR DEVELOPMENT}

\section{Emergence of New and/or More Relevant Theories and Concepts}

The theory, policy, practice dance metaphor can also help point out constructive and creative encounters between dancing partners. Examples include theories, models, approaches and concepts that are either new or renewed, are claimed to be more relevant and have the potential to orient public policies and practices in the desired direction in emerging countries:

a. Amartya Sen's (2000) approach to development, which defines development as freedom. This idea, taken up by Cozzens et al., who define knowledge as freedom and therefore knowledge as development (Cozzens et al. 2008), highlights the role of local knowledge and education on development, supporting positioning innovation 'below the policymakers' radar' in emerging countries.

b. The Sábato Triangle model (Sábato and Botana 1968). This actually is not new. It's even older than its related concept embodied in the so-called Triple Helix model discussed earlier. This model of knowledge production highlights the importance of participatory processes on decision making and, more importantly, on the role of governments not so much as knowledge producers (as is the case in the Triple Helix model) but as knowledge production and dissemination enablers.

c. The Bogotá Manual (Jaramillo et al. 2001), which highlights the importance of innovative capabilities and activities as opposed to innovation for the world. It targets 'new' actors and activities judged important to innovation happening and to capability development to sustain it.

d. The Regional Innovation Systems (Cooke et al. 1997) and the 
Clusters approaches (Roelandt and den Hertog 1999; Cooke 2001; den Hertog et al. 2001; Benneworth and Henry 2004) to innovation. These highlight the role of local, sub-national and sectoral capabilities and determinants and orient targeted efforts to take advantage of local strengths and address deficiencies judged strategic for development, therefore improving the conditions for legitimacy of innovation and their related policies and programmes.

e. The export-led models of development (Etzkowitz and Brisolla 1999). These models highlight the role of competition and high quality standards, constituting a clear target for catching up and reducing monopoly power, inefficiency and, as proved to be the case in the import substitution model, corruption.

f. The concept of social innovation (Andrew and Klein 2010; Howaldt and Schwarz 2010; Edwards-Schachter et al. 2012; Nicholls et al. 2015). This concept points to the importance of communities as key innovation policy targets, among other implications that are discussed later.

g. The concept of frugal innovation (Bhatti 2012; Bound and Thornton 2012; Radjou et al. 2012). This responds to limitations in resources, whether financial, material or institutional, and uses a range of methods, turning these constraints into an advantage. 'Successful frugal innovations are not only low cost, but outperform the alternative, and can be made available at large scale. Often, but not always, frugal innovations have an explicitly social mission' (Bound and Thornton 2012, p.6).

Indeed, recent innovation studies show that, more often than not, innovations in emerging countries occur outside of the formal $R \& D$ system, in the informal economy. Active research is being conducted to identify alternative development paths building from the intensive use of science, technology and innovation aiming at reducing poverty and promoting social inclusion, as well as better understanding the bottlenecks that prevent innovations achieved in the informal economy from scaling up. The chapters by Marcelle (Chapter 2), Djeflat (Chapter 5), Loconto and Simbua (Chapter 9), Orozco (Chapter 10), Oyewale et al. (Chapter 12), Arocena and Sutz (Chapter 13), Voeten (Chapter 14), Catalán (Chapter 15) and Thomas et al. (Chapter 17) in this book are contributions to these debates. 
The result has been the emergence of a new field, one that cuts across innovation scholarship and development studies, where innovation investments are expected to address the social needs of the most vulnerable groups. It has also led to a new paradigm of innovation policy, where new approaches highlighting the social dimension of science, technology and innovation have become increasingly strong, offering alternative views to the traditional economic orientation of such activities and related policies, and claiming there is a need to diversify government intervention for integrating demands from sectors that typically have no voice within the science, technology or innovation agendas. Such perspectives are increasingly advocated both in academia (Gupta 1995; Prahalad and Hart 2002; Cassiolato and Lastres 2008; Cozzens et al. 2008; Arocena and Sutz 2010; Bhatti 2012; Nicholls et al. 2015; Balanzó Guzman 2016) and in international organizations (UN/ECLAC 2010; World Bank 2010; OECD 2012), and have taken different ideological traits apart from traditional concepts and theories of innovation.

These are approaches that a) give a central role to the communities and therefore reject the traditional dichotomy between users and producers of knowledge and innovation; $b$ ) see innovation as a factor of empowerment in itself; and c) seek to expand and exploit the potential market-base of low-income people by encouraging companies to produce innovations with low costs on products and services. It is for that reason that one witnesses a great boom in the literature and political debates in several emerging countries concepts such as the 'bottom of the pyramid' (BOP) (Prahalad and Hart 2002; Cholez et al. 2012), grassroots innovation (Gupta 1995), frugal innovation (Bhatti 2012) and innovation for inclusion (see Arocena and Sutz, Chapter 13 in this book; and Alzugaray et al. 2012; Garrido and Lalouf 2012), or even concepts such as social innovation (see Thomas et al., Chapter 17 in this book; and Nicholls et al. 2015), which is also seen as a complement to (and for many a determinant of) technological innovation (Edwards-Schachter et al. 2012). A survey of such approaches is found in a special issue of Review of Policy Research (Bortagaray and Ordóñez-Matamoros 2012), where new institutional arrangements are recognized as key 'bridges' between innovation and society (see Arocena and Sutz, Chapter 13 in this book; and Dutrénit et al. 2012).

There are indeed emerging concerns in the innovation policy research literature in emerging countries, which take place parallel to related debates over the so-called 'grand challenges' 
(Kuhlmann and Rip 2015) and 'responsible research and innovation' (RRI) ${ }^{15}$ (Owen et al. 2012, 2013; von Schomberg 2013), concepts increasingly seen as objects of innovation policy in both the European Union and the USA, perhaps fuelled by the increasing realization of climate change and an astonishing increase in income inequality (Cozzens and Kaplinsky 2009; Piketty 2014). Vasen (2015) explores the interaction between the 'responsible research and innovation' framework and the de facto dominant focus on competitiveness in innovation policy in Latin America (Casas et al. 2013). He assesses the extent to which the nature of values advanced by RRI is in fact embedded in those values, grounding the Latin American innovation policy agenda in innovation for social inclusion, technologies for social inclusion or grassroots innovations or, alternatively, whether RRI values refer to a Eurocentric approach (Davis and Laas 2014) par excellence. According to the author, the RRI framework does not support an axiological pluralism where European values are intrinsically interwoven excluding any imbrication with Latin American values and contexts (Vasen 2015).

In a similar vein, Kuhlmann et al. (2015) developed a governance framework (the Responsibility Navigator ${ }^{16}$ ) for materializing the responsible innovation concept in Europe which pulled together academic networks that expand its outreach to other world regions. We are witnessing, in fact, a co-evolution between, on the one hand, the social innovation and social inclusion family of concepts and, on the other, the European, grand challenges and RRI family of concepts, where a non-economic emphasis is shared by both types of approaches, as both are considered a reaction to the commercial or growth-based emphasis of mainstream innovation policy making and literature.

\section{Emergence of New and More Relevant Policies and Programmes}

This new generation of approaches has led to a new generation of policies implemented in some countries as expressed in their innovation national plans, which aim at combining innovation investment and the social demands of the poorest people. The chapters by Rennkamp (Chapter 3) and Djeflat (Chapter 5) in this book offer examples of this trend.

However, while in some countries important progress has been made, in others the challenge is still too difficult. The 
reason is that, as discussed earlier, states' abilities to induce and prioritize agendas vary along with the market or community orientation that these approaches assume. In fact, in most of these countries' governments the focus is on the growth-based challenges. Regarding some Andean countries, for example, Gras and Bortagaray (2013) found that the incorporation of the innovation for social inclusion perspective has not been translated into tools that effectively generate inclusion. One of the reasons claimed by the authors has been the definitions' lack of clarity, with the corresponding ambiguity in the operationalization of programmes. However, it is perhaps still too early to judge the success or failure of such approaches as operationalized in policies and programmes in some of the implementing countries.

Similarly, Couto and Tomassini (2015) analysed how and through which perspectives and mechanisms the relationship between innovation policies and social inclusion has been considered in the BRICS countries. Their paper compares institutional arrangements to articulate innovation policies and social inclusion. They conclude that, 'despite the increasing attention on innovation role for social inclusion, the National Innovation Systems (NIS) in BRICS still show a weak coordination with social policies' (Couto and Tomassini 2015). According to the authors, Brazil, which is nowadays internationally known by the implementation of distributive policies, shows remarkable effects on reducing inequality, where the income improvement has expanded the domestic market, with millions of Brazilians stepping out of poverty and entering the consumption market. How much of that success is due to innovation policies aimed at fostering inclusive innovation? That is, the authors claim, still a subject of debate, however. In Russia, they found that in Strategy 2020 the initiatives aimed at integration of vulnerable social groups through innovation processes are marginal. Furthermore, they did not find a systemic or formalized innovation policy aimed at social inclusion. India appears to be the country with a longer tradition in the application of these perspectives, especially the grassroots innovation (Gupta 1995) and frugal innovation approaches (Bound and Thornton 2012; Radjou et al. 2012), where the incorporation of these perspectives within formal institutions of innovation has led to the building of a complex network driven towards the social inclusion goal. However, according to the authors, results are still weak (Couto and Tomassini 2015). By contrast, in the case of China, the authors found that in the last 
decade the country has put the aim of improving people's quality of life at the top of the agenda, and for the first time the innovation programme gives priority to the promotion of technologies related to that end. A similar trend was found in the case of South Africa, where, according to the authors, the country shows a transition from concerns about improving public services towards an increasing attention to poverty reduction. This finding is somewhat consistent with those in Rennkamp's (Chapter 3) and Scerri's (Chapter 4) chapters in this book.

It seems overall that the final outcome of this 'turn' from the traditional growth- and competitiveness-based innovation policy towards a more socially distributive-, inclusive-based innovation policy is yet to be assessed. For this purpose, careful policy analysis and evaluation are indeed needed. The chapters in this book can be read as contributions to this aim.

\section{THE CHAPTERS IN THIS BOOK}

The book is divided into three parts, each analysing one of the three dancers of the policy dance configuration of a country or group of countries: the chapters focusing (mostly but not exclusively) on the theoretical challenges and opportunities emerging countries typically face, those discussing mainly governance and policy challenges and opportunities, and those relating mostly to innovation practice challenges and opportunities in the studied countries' contexts.

\section{Theoretical Challenges and Opportunities}

Delvenne and Thoreau (Chapter 1) question the extent to which the NIS approach is adequate to reflect non-OECD realities. They claim that, in order to positively affect the systems in Latin American countries, policy makers should look at such an approach reflexively and use it with a more encompassing scope, allowing the integration of greater diversity and complexity. The authors call for the need to define a research agenda for engaging NISs both conceptually and practically.

Marcelle (Chapter 2) claims that knowledge and innovation policies have failed to encourage innovation in emerging countries mostly because they are inspired by the wrong models without questioning their relevance. According to the author, 
innovation studies should open up to new voices and perspectives from the global South, question the status quo more and listen to local performers more. In the process, the author claims, innovation scholars should focus more on micro-foundation explanations, learning and capability building.

Rennkamp (Chapter 3) inquires in her chapter about the role innovation theory, policy and practice play to account for the steep income inequalities in emerging countries. In so doing, the author studies the cases of Brazil and South Africa, and finds that theories and policies continue to derive from experiences in the industrialized nations, and that in emerging countries inequality-, social- and pro-poor-oriented innovations and policies are paradoxically not a priority. According to the author, while Brazil is making more progress than South Africa with skills development programmes to boost innovation, the bulk of the knowledge and innovation policies in both countries are still inspired by European models rather than being designed according to the local practitioners' needs.

Scerri (Chapter 4) questions how innovation systems' trajectories in emerging countries can be explained. The author offers a classification of African NISs based on a 'modes of innovation' concept developed from a theory of value formulated in terms of streams of innovation. Hence, after studying the cases of South Africa and Tanzania, two outliers within the generalized context of African post-colonial history, the author offers policy implications of his approach.

Djeflat (Chapter 5) claims that the NIS approach has not been appropriately used to trigger innovation in emerging countries and in Northern Africa in particular. This, the author claims, is mostly due to a poor understanding of how innovation emerges in non-catch-up countries. For this reason, the author suggests the emerging innovation systems approach, as according to the author it reflects much better the realities and needs in those countries by focusing on the determinants of innovation emergence. However, for this approach to work and become a normative model, the author adds, strong policy impulses are needed, as well as adequate market dynamics.

\section{Governance Challenges and Opportunities}

Chaminade and Padilla-Pérez (Chapter 6) explore the barriers for designing and implementing effective policies in emerging 
countries, where alignment of STI policies with the national economic development agenda has not been possible for the most part. In particular, the authors look at barriers for horizontal alignment between ministries and other public organizations, as well as for vertical alignment of rationales, objectives, instruments and specific problems of the systems. They claim that emerging countries need policies that are comprehensive, evidence based, long-term and aligned in order for them to be effective and contribute to development.

Dutrénit and Puchet (Chapter 7) question the role of institutional frameworks, the rules of the game in operation in the system, the governance at different levels, and using the political economy to explain and trigger or block innovation practice and policy in emerging countries. In so doing, the authors examine the interplay between the trajectory of institutional building, the process of construction of both government and governance of the NSI, and the political economy in Mexico.

Salazar (Chapter 8) explores the new context of the Colombian innovation system, represented by a) a new law creating a new fund and granting 10 per cent of the mining royalties to research and innovation activities; and b) the creation of a new institution aiming at encouraging innovation and entrepreneurship (iNNpulsa) in Colombia. The author analyses their effects in terms of opportunities, challenges and threats to Colciencias, the Colombian national science foundation, and to the governance of the entire system. More importantly, the author questions whether Colciencias's learning accumulated over the past 45 years will be valued, adapted, utilized or wasted in the years to come.

Loconto and Simbua (Chapter 9) show how incremental innovation and government performance, as reflected in the Tanzanian tea research sector, result from learning by 'tinkering', using and interacting, both by innovators and by policy makers. According to the authors, in the case of Tanzania, theory dominates the 'dance', but only in rhetoric.

Based on the systems literature and arguments, on the global commodity chains literature, and on inclusive growth and interactive learning scholarship, Orozco (Chapter 10) studies innovation processes in the fishing sector in the Gulf of Fonseca in Central America and concludes that the conditions of governance within the value chain hinder the options to innovate, where short-term policies compromise the sustainability of the fishery resources, and where new knowledge and transfer are 
impossible owing to the lack of resources from the government and the market, while innovation is encouraged in other neighbouring sectors such as tourism and agriculture.

Mani (Chapter 11) assesses the extent to which national and sectoral policies attempting to increase local innovation through subsidies to R\&D and intellectual property rights protection in India have led to the intended results. The author finds that the policies implemented have resulted mostly in the concentration of research in certain sectors, while no conclusive improvement of research performance can be claimed. The author explains that the causes of such results can be attributed to research and innovation policies.

Oyewale et al. (Chapter 12) study research and innovation policy making and impact in Nigeria. They conclude that, owing to inadequate policy formulation processes and little interaction between and within government, industry and research and innovation actors, weak results are obtained at the system level. According to the authors, a more inclusive policy formulation process has taken place in the framework of a new research and innovation policy, which results in mutually beneficial interactions and promotes an effective innovation policy dance.

\section{Innovation Practice Challenges and Opportunities}

Arocena and Sutz (Chapter 13) are mainly concerned with how research and innovation impact society. They look at ways these activities should be performed to improve social inclusion: a) directly, through improving competitiveness and job creation; b) indirectly, through programmes focused specifically for that purpose by appealing to bottom-up processes involving the target populations; or c) in a combination with top-down processes promoting the performance and result for the poor. In this sense, according to the authors, 'knowledge democratization', where universities have a key role to play, as well as keeping a close link between STI policies and broader social policies, is particularly important.

Voeten (Chapter 14) examines the role of informal institutions on national innovation systems in emerging countries. To do this the author analyses the case of Vietnam, where these sorts of institutions provide an enabling environment for innovation and, in so doing, complement the role of innovation policy. According to the author, inclusive innovation, conceived as a 
societal process, is a determinant for progress, and therefore specific policies designed to support those processes are required.

Catalán (Chapter 15) looks at the role of rural communitybased innovation systems, and particularly the water supply and sanitation system, to better understand the extent to which collaboration, leadership, skills and sense of ownership drive innovation in the case of Costa Rica. According to the author, lack of collaboration between experts, policy makers, innovators and users may lead to service system crisis.

Robles-Belmont and Vinck (Chapter 16) claim that innovation results through processes of mutual learning with all sorts of actors, including a relatively new set of actors emerging on the scene in emerging countries, such as non-governmental and/or philanthropic organizations. The authors arrive at that conclusion after analysing the role of the Mexico-United States Foundation for Science, which plays an important role in microtechnologies in Mexico. The authors' main question then is how to model the relationships among different organizations involved in the production, use and dissemination of new knowledge. The authors conclude that new functions are being fulfilled by those new types of actors, leading to new (joint) arrangements ensuring the functioning of the system.

Last but not least, motivated to understand how governments could avoid the failures of the past in the development of technologies for social inclusion in Latin America, Thomas et al. (Chapter 17) claim that theoretical failures referring to the use of the linear model of innovation and its overreliance on the old concern about technology transfer should be avoided, together with avoiding policy failures resulting from the lack of investment in human resources, the discontinuity of funding for projects, the inability of development institutions to implement long-term strategies based on learning improvements, and so on, as these factors seem to explain why and how knowledge and innovation policy initiatives aiming to improve social inclusion fail. Their conclusions are based on the study of cases in social housing, renewable energy and food production in Argentina, where the authors analysed the ways actors strive to cope with such failures. 


\section{NOTES}

1. The authors would like to thank Maria Alejandra Tejada and Alejandro Balanzó at the University of Twente, and Mónica Olmedo and Angie Franco at the Universidad Externado de Colombia, for their assistance with this chapter.

2. The MDGs for 2000-2015 included: 1) eradicate extreme poverty and hunger; 2 ) achieve universal primary education; 3) promote gender equality and empower women; 4) reduce child mortality; 5) improve maternal health; 6) combat HIV/ AIDS, malaria and other diseases; 7) ensure environmental sustainability; and 8) develop a global partnership for development. These goals are supported by 21 specific targets and more than 60 indicators.

3. See UN 2015 Millennium Development Goals Report at http://www.un.org/ millenniumgoals/2015_MDG_Report/pdf/MDG\%202015\%20PR\%20Key\%20 Facts\%20Global.pdf.

4. See OECD, accessed 26 January 2016 at www.oecd.org/social/inequality.htm.

5. The SDGs 2015-30 include: 1 ) end poverty in all its forms everywhere; 2 ) end hunger, achieve food security and improved nutrition and promote sustainable agriculture; 3) ensure healthy lives and promote well-being for all at all ages; 4) ensure inclusive and equitable quality education and promote lifelong learning opportunities for all; 5) achieve gender equality and empower all women and girls; 6) ensure availability and sustainable management of water and sanitation for all; 7) ensure access to affordable, reliable, sustainable and modern energy for all; 8) promote sustained, inclusive and sustainable economic growth, full and productive employment and decent work for all; 9) build resilient infrastructure, promote inclusive and sustainable industrialization and foster innovation; 10) reduce inequality within and among countries; 11) make cities and human settlements inclusive, safe, resilient and sustainable; 12) ensure sustainable consumption and production patterns; 13) take urgent action to combat climate change and its impacts; 14) conserve and sustainably use the oceans, seas and marine resources for sustainable development; 15) protect, restore and promote sustainable use of terrestrial ecosystems, sustainably manage forests, combat desertification, and halt and reverse land degradation and biodiversity loss; 16) promote peaceful and inclusive societies for sustainable development, provide access to justice for all and build effective, accountable and inclusive institutions at all levels; and 17) strengthen the means of implementation and revitalize the global partnership for sustainable development. These involved the support of 169 targets and 304 indicators.

6. In the following we use 'innovation' and 'innovation governance' as an abbreviation for the entire spectrum of knowledge, science, technology and innovation and the related public policies and decision-making procedures (following Kuhlmann 2001).

7. See for example Padma (2015).

8. Alternatively, and reinforcing the idea that all countries are emerging, one can also find similarities between apparently dissimilar countries such as Colombia and the Netherlands in relation to, for example, the challenge to encourage private corporations to produce public goods (such as environment protection).

9. One could say that the first case gives an account of a harm caused under the responsibility of the proponent of the model or theory in question, and the second one gives an account where the one responsible for the harm is the applicant of the model or theory, that is, the policy maker or the entrepreneur or social actor.

10. In the policy studies literature this problem is known as the 'Type Three Error', described in detail in Ordóñez-Matamoros et al. (2013), and in Dunn (2016), which involves 'solving the wrong problem' because of, among other factors, policies and programmes inspired by bad or wrong causal theories or assumptions.

11. This manual was then updated in OECD/Eurostat (2005).

12. This manual has recently been updated in OECD (2015).

13. According to Ordóñez-Matamoros et al. (2013), playing the role of solution 


\section{Research handbook on innovation governance for emerging economies}

advocates is not a bad thing per se, as long as it is played at the right moment, that is, when a 'good enough' solution has been found to be appropriate, and not when a problem is being structured or framed with the purpose of finding the appropriate solution, as this will most likely lead to bias.

14. See www.globelics.org. More recently, forums such as the Eu-SPRI Forum Conferences (http://www.euspri-forum.eu/) and the Atlanta Conference on Science and Innovation Policy (www.atlantaconference.org) are increasingly serving as platforms to discuss these issues focusing on emerging countries cases.

15. This concept arose in the context of research on nanotechnology, particularly in the context of the National Nanotechnology Initiative in the United States in the early 2000s, under the idea of 'responsible development', and then evolved in the European context with an expanded scope referring to all types of research and innovation fields, and then it gained a central place in the European research and innovation funding strategy Horizon 2020.

16. See www.responsibility-navigator.eu.

\section{REFERENCES}

Acs, Z.J. (2000), Regional Innovation, Knowledge and Global Change, London: Pinter.

Acs, Z., J. de la Mothe and G. Paquet (1996), 'Local Systems of Innovation: In Search of an Enabling Strategy', in P. Howitt (ed.), The Implications of Knowledge-based Growth for Micro-economic Policies, Calgary: University of Calgary Press, pp.339-358.

Alzugaray, S., L. Mederos and J. Sutz (2012), 'Building Bridges: Social Inclusion Problems as Research and Innovation Issues', Review of Policy Research, 29 (6), 776-796.

Andrew, C. and J.L. Klein (2010), Social Innovation: What Is It and Why Is It Important to Understand It Better, Cahiers du Centre de recherche sur les innovations sociales (CRISES) Collection Études théoriques no. ET1003, Toronto, Canada: Ontario Ministry of Research and Innovation.

Archibugi, D. and C. Pietrobelli (2003), 'The Globalisation of Technology and Its Implications for Developing Countries - Windows of Opportunity or Further Burden?', Technological Forecasting and Social Change, 70 (9), 861-883.

Arocena, R. and J. Sutz (2001), 'Changing Knowledge Production and Latin American Universities', Research Policy, 30 (8), 1221-1234.

Arocena, R. and J.Sutz (2003), 'Knowledge, Innovation and Learning: Systems and Policies in the North and in the South', in J.E. Cassiolato, H.M.M. Lastres and M.L. Maciel (eds), Systems of Innovation and Development: Evidence from Brazil, Cheltenham, UK and Northampton, MA, USA: Edward Elgar, pp. 291-310.

Arocena, R. and J. Sutz (2006), 'El estudio de la innovación desde el Sur y las perspectivas de un Nuevo Desarrollo', Revista Iberoamericana de Ciencia, Tecnología, Sociedad, Innovación, accessed at http://www.oei.es/revistactsi/numero7/articulo01.htm(7).

Arocena, R. and J. Sutz (2010), 'Research and Innovation Policies for Social Inclusion: Is There an Emerging Pattern?', Paper presented at the 8th Globelics Conference: 'Making Innovation Work for Society: Linking, Leveraging and Learning', University of Malaysia, Kuala Lumpur, Malaysia, 1-3 November.

Balanzó Guzman, A. (2016), Unfolding Capacity. Strategies of Farmer's Organisations as Change Agents, PhD thesis, Enschede: University of Twente.

Benneworth, P. and N. Henry (2004), 'Where Is the Value Added in the Cluster Approach? Hermeneutic Theorising, Economic Geography and Clusters as a Multiperspectival Approach', Urban Studies, 41 (5-6), 1011-1023.

Bhatti, Y. (2012), 'What Is Frugal, What Is Innovation? Towards a Theory of Frugal Innovation', Working paper, University of Oxford, Said Business School, Oxford Centre for Entrepreneurship and Innovation, accessed at http://ssrn.com/abstract=2005910.

Bortagaray, I. and G. Ordóñez-Matamoros (2012), 'Introduction to the Special Issue of 
the Review of Policy Research: Innovation, Innovation Policy, and Social Inclusion in Developing Countries', Review of Policy Research, 29 (6), 669-671.

Bound, K. and I. Thornton (2012), Our Frugal Future: Lessons from India's Innovation System, London: NESTA.

Bozeman, B. (2000), 'Technology Transfer and Public Policy: A Review of Research and Theory', Research Policy, 29 (4-5), 627-655.

Brown, R., G. Gregson and C. Mason (2015), 'A Post-mortem of Regional Innovation Policy Failure: Scotland's Intermediate Technology Initiative (ITI)', Regional Studies, accessed at http://dx.doi.org/10.1080/00343404.2014.985644.

Carlsson, B. and S. Jacobsson (1994), 'Technological Systems and Economic Policy: The Diffusion of Factory Automation in Sweden', Research Policy, 23 (3), 235-248.

Casas, R., J.M. Corona and R. Rivera (2013), 'Políticas de Ciencia, Tecnología e Innovación en América Latina: Entre la Competitividad y la Inclusión Social', Conferencia Internacional LALICS: 'Sistemas Nacionales de Innovación y Políticas de CTI para el Desarrollo Inclusivo y Sostenible', Rio de Janeiro, Brazil, 11-12 November.

Cassiolato, J.E. and H.M.M. Lastres (2008), 'Discussing Innovation and Development: Converging Points between the Latin American School and the Innovation Systems Perspective?', 5th International Ph.D. School on Innovation and Economic Development, Globelics Academy, Tampere, Finland, 2-13 June.

Cholez, C., P. Trompette, D. Vinck and T. Reverdy (2012), 'Bridging Access to Electricity through BOP Markets: Between Economic Equations and Political Configurations', Review of Policy Research, 29 (6), 713-732.

Cooke, P. (2001), 'Regional Innovation Systems, Clusters, and the Knowledge Economy', Industrial and Corporate Change, 10 (4), 945-974.

Cooke, P., M.G. Uranga and G. Etxebarria (1997), 'Regional Innovation Systems: Institutional and Organisational Dimensions', Research Policy, 26 (4-5), 475-491.

Couto, S. and C. Tomassini (2015), 'Inclusive Development in Science, Technology and Innovation Policy of the BRICS', Paper presented at the 2015 Atlanta Conference on Science and Innovation Policy, Atlanta, GA, USA, 17-19 September.

Cozzens, S.E. and R. Kaplinsky (2009), 'Innovation, Poverty and Inequality: Cause, Coincidence, or Co-evolution?', in B.-Å. Lundvall, K.J. Joseph, C. Chaminade and J. Vang (eds), Handbook of Innovation Systems and Developing Countries: Building Domestic Capabilities in a Global Setting, Cheltenham, UK and Northampton, MA, USA: Edward Elgar, pp. 57-82.

Cozzens, S.E., S. Gatchair, K.-S. Kim, H.G. Ordóñez-Matamoros and A. Supnithadnaporn (2008), 'Knowledge and Development', in E.J. Hackett, O. Amsterdamska, M. Lynch and J. Wajcman (eds), The Handbook of Science and Technology Studies, Cambridge, MA, USA: MIT Press, pp.787-812.

Dagnino, R. and H. Thomas (2001), 'Planejamento e Políticas Públicas de Inovação: Em Direção a um Marco de Referência Latino-Americano', Planejamento e Políticas Públicas, 23, 205-231.

Davis, M. and K. Laas (2014), "Broader Impacts" or "Responsible Research and Innovation"? A Comparison of Two Criteria for Funding Research in Science and Engineering', Science and Engineering Ethics, 20 (4), 963-983.

Dunn, W.N. (2016), Public Policy Analysis: An Introduction, New York: Routledge.

Dutrénit, G., A. Rocha-Lackiz and A.O. Vera-Cruz (2012), 'Functions of the Intermediary Organizations for Agricultural Innovation in Mexico: The Chiapas Produce Foundation', Review of Policy Research, 29 (6), 693-712.

Edquist, C. (1997), Systems of Innovation: Technologies, Institutions, and Organizations, London: Pinter.

Edwards-Schachter, M., C. E. Matti and E. Alcántara (2012), ‘Fostering Quality of Life through Social Innovation: A Living Lab Methodology Study Case', Review of Policy Research, 29 (6), 672-692.

Etzkowitz, H. and S.N. Brisolla (1999), 'Failure and Success: The Fate of Industrial Policy in Latin America and South East Asia', Research Policy, 28 (4), 337-350. 


\section{Research handbook on innovation governance for emerging economies}

Etzkowitz, H. and L. Leydesdorff (2000), 'The Dynamics of Innovation: From National Systems and "Mode 2" to a Triple Helix of University-Industry-Government Relations', Research Policy, 29 (2), 109-123.

Freeman, C. (1987), Technology Policy and Economic Performance: Lessons from Japan, London: Pinter.

Fukuyama, F. (2001), 'Social Capital, Civil Society and Development', Third World Quarterly, 22 (1), 7-20.

Garrido, S. and A. Lalouf (2012), 'The Socio-technical Alliance: Bringing New Tools to the Design of Policies Aimed to Promote Social Inclusion', Review of Policy Research, 29 (6), 733-751.

Gibbons, M., C. Limoges, H. Nowotny, S. Schwartzman, P. Scott and M. Trow (1994), The New Production of Knowledge: The Dynamics of Science and Research in Contemporary Societies, London: Sage.

Gras, N. and I. Bortagaray (2013), 'Políticas de Ciencia, Tecnología e Innovación para el Desarrollo Inclusivo: Tendencias Cambiantes en América del Sur', Conferencia Internacional LALICS: 'Sistemas Nacionales de Innovación y Políticas de CTI para el Desarrollo Inclusivo y Sostenible', Rio de Janeiro, Brazil, 11-12 November.

Gupta, A. (1995), 'People's Knowledge for Survival: Grassroots Innovations for Sustainable Natural Resource Management', Paper presented at the IFAD International Conference on Hunger and Poverty, Brussels, Belgium, 16-23 November.

Hertog, P. den, E.M. Bergman, D. Charles and S. Remoe (2001), Innovative Clusters: Drivers of National Innovation Systems, Paris: OECD.

Howaldt, J. and M. Schwarz (2010), Social Innovation: Concepts, Research Fields and International Trends, Report, Dortmund, Germany: ESF, EU and Aachen University.

Hurtado, D. and E. Mallo (2012), 'Riesgos teóricos y agenda de políticas: El "mal del modelo lineal" y las instituciones de CyT como cajas negras', in H. Thomas, M. Fressoli and G. Santos (eds), Tecnología, Desarrollo y Democracia: Nueve estudios sobre dinámicas socio-técnicas de exclusión/inclusión social, Buenos Aires, Argentina: Ministerio de Ciencia, Tecnología e Innovación Productiva e Instituto de Estudios sobre la Ciencia y la Tecnología - Universidad Nacional de Quilmes (IESCT-UNQ), pp. 225-244.

Jaramillo, H., G. Lugones and M. Salazar (2001), Normalización de Indicadores de Innovación Tecnológica en América Latina y el Caribe - Manual de Bogotá, Bogotá, Colombia: RICYT/ OEA/CYTED/COLCIENCIAS/OCYT.

Kline, S. and N. Rosenberg (1986), 'An Overview of Innovation', in R. Landau and N. Rosenberg (eds), The Positive Sum Strategy: Harnessing Technology for Economic Growth, Washington, DC: National Academy Press, pp.275-305.

Kuhlmann, S. (2001), 'Future Governance of Innovation Policy in Europe - Three Scenarios', Research Policy, 30 (6), 953-976.

Kuhlmann, S. and A. Rip (2015), 'New Constellations of Actors Addressing Grand Challenges: Evolving Concertation', Paper presented at the KISTEP workshop 'Inside and Insight', Seoul, Republic of Korea, 8-11 September.

Kuhlmann, S., P. Boekholt, L. Georghiou, K. Guy, J.-A. Heraud, P. Laredo, T. Lemola, D. Loveridge, T. Luukkonen, A. Moniz, W. Polt, A. Rip, L. Sanz-Menendez and R. Smits (1999), 'Improving Distributed Intelligence in Complex Innovation Systems', Final report of the Advanced Science and Technology Policy Planning Network (ASTPP), European Targeted Socio-economic Research Programme, Karlsruhe, accessed at http:/ / mpra.ub.uni-muenchen.de/6426/, pp.1-87.

Kuhlmann, S., P. Shapira and R.E. Smits (2010), 'Introduction: A Systemic Perspective: The Innovation Policy Dance', in R.E. Smits, S. Kuhlmann and P. Shapira (eds), The Theory and Practice of Innovation Policy: An International Research Handbook, Cheltenham, UK and Northampton, MA, USA: Edward Elgar, pp. 1-22.

Kuhlmann, S., J. Edler, G. Ordóñez-Matamoros, S. Randles, B. Walhout, C. Gough and R. Lindner (2015), 'Responsibility Navigator', Fraunhofer Institute for Systems and Innovation Research ISI, Karlsruhe, accessed at www.responsibility-navigator.eu.

Lee, W.Y. (2000), 'The Role of Science and Technology Policy in Korea's Industrial 
Development', in K. Kim and R.R. Nelson (eds), Technology, Learning and Innovation: Experiences of Newly Industrializing Economies, Cambridge, UK: Cambridge University Press, pp. 269-290.

Leydesdorff, L. (2000), 'The Triple Helix: An Evolutionary Model of Innovations', Research Policy, 29 (2), 243-255.

Lundvall, B.-A.. (ed.) (1992), National Systems of Innovation: Towards a Theory of Innovation and Interactive Learning, London: Pinter.

Lundvall, B.-Å., K.J. Joseph, C. Chaminade and J. Vang (2009), Handbook of Innovation Systems and Developing Countries: Building Domestic Capabilities in a Global Setting, Cheltenham, UK and Northampton, MA, USA: Edward Elgar.

Luukkonen, T., O. Persson and G. Sivertsen (1992), 'Understanding Patterns of International Scientific Collaboration', Science Technology and Human Values, 17 (1), 101-126.

Malerba, F. (2002), 'Sectoral Systems of Innovation and Production', Research Policy, $31(2), 247-264$.

McGrail, M.R., C.M. Rickard and R. Jones (2006), 'Publish or Perish: A Systematic Review of Interventions to Increase Academic Publication Rates', Higher Education Research and Development, 25 (1), 19-35.

Mowery, D. (1997), 'The Bush Report after Fifty Years - Blueprint or Relic?', in C.E. Barfield (ed.), Science for the Twenty-first Century: The Bush Report Revisited, Washington, DC: AEI Press, pp. 24-41.

Muchie, M., P. Gammeltoft and B.-Å. Lundvall (2003), Putting Africa First: The Making of African Innovation Systems, Aalborg, Denmark: Aalborg University Press.

Nelson, R.R. (ed.) (1993), National Innovation Systems: A Comparative Analysis, New York: Oxford University Press.

Nicholls, A., J. Simon and M. Gabriel (eds) (2015), New Frontiers in Social Innovation Research, Houndmills, UK: Palgrave Macmillan.

OECD (1997), Oslo Manual: The Measurement of Scientific and Technological Activities: Proposed Guidelines for Collecting and Interpreting Technological Innovation Data, accessed at http://www.oecd.org/pdf/M00018000/M00018312.pdf.

OECD (2012), 'Innovation and Inclusive Development', Discussion report for the conference 'Innovation for Inclusive Development', Cape Town, South Africa, 21 November.

OECD (2015), Frascati Manual 2015: Guidelines for Collecting and Reporting Data on Research and Experimental Development, Paris: OECD Publishing.

OECD/Eurostat (2005), Oslo Manual: Guidelines for Collecting and Interpreting Innovation Data, Paris: OECD Publishing.

Ordóñez-Matamoros, H.G., S. Tadlaoui, S. Porras, J. Duarte, L. López, L. Martínez and G. Calderón (2013), Manual de Análisis y Diseño de Políticas Públicas, Bogotá, Colombia: Universidad Externado de Colombia.

Oteiza, E. (1992), La Política de investigación científica y tecnológica Argentina: Historia y perspectivas, Buenos Aires, Argentina: Centro Editor de América Latina.

Owen, R., P. Macnaghten and J. Stilgoe (2012), 'Responsible Research and Innovation: From Science in Society to Science for Society, with Society', Science and Public Policy, 39, 751-760.

Owen, R., J. Bessant and M. Heintz (2013), Responsible Innovation: Managing the Responsible Emergence of Science and Innovation in Society, Chichester, UK: John Wiley \& Sons.

Padma, T.V. (2015), 'India's Budget Disappoints Scientists', Nature, 2 March.

Palley, T.I. (2005), 'From Keynesianism to Neoliberalism: Shifting Paradigms in Economics', in A. Saad-Filho and D. Johnston, Neoliberalism: A Critical Reader, London: Pluto Press, pp. 20-29.

Perez, C. (1996), 'La modernización industrial en América Latina y la herencia de la sustitución de importaciones', Comercio exterior, 46 (5), 347-363.

Perez, C. (2012), Innovation Systems and Policy: Not Only for the Rich?, Working Paper in Technology Governance and Economic Dynamics no. 42, Norway and Tallinn, Estonia: Other Canon Foundation and Tallinn University of Technology. 


\section{Research handbook on innovation governance for emerging economies}

Piketty, T. (2014), Capital in the Twenty-first Century, Cambridge, MA, USA: Belknap Press of Harvard University Press.

Prahalad, C.K. and S.L. Hart (2002), 'The Fortune at the Bottom of the Pyramid', Strategy + Business, 26, 1-16.

Radjou, N., J. Prabhu and S. Ahuja (2012), Jugaad Innovation: Think Frugal, Be Flexible, Generate Breakthrough Growth, San Francisco, CA, USA: John Wiley \& Sons.

Roelandt, T.J. and P. den Hertog (1999), 'Cluster Analysis and Cluster-based Policy Making in OECD Countries: An Introduction to the Theme', in OECD (ed.), Boosting Innovation: The Cluster Approach, Paris: OECD Publishing, pp.9-23.

Sábato, J. and N. Botana (1968), 'La ciencia y la tecnología en el desarrollo futuro de América Latina', Revista de la Integración, 3, 1-11.

Sagasti, F. (2004), Knowledge and Innovation for Development: The Sisyphus Challenge of the 21st Century, Cheltenham, UK and Northampton, MA, USA: Edward Elgar.

Scerri, M. and H.M.M. Lastres (2013), BRICS - National Systems of Innovation: The Role of the State, New Delhi, India: Routledge.

Schomberg, R. von (2013), 'A Vision of Responsible Research and Innovation', in R. Owen, M. Heintz and J. Bessant (eds), Responsible Innovation: Managing the Responsible Emergence of Science and Innovation in Society, Chichester, UK: John Wiley \& Sons, pp. 51-74.

Sen, A. (2000), Development as Freedom, New York: Anchor Books.

Silva, E. (2007), 'The Import-substitution Model: Chile in Comparative Perspective', Latin American Perspectives, 34 (3), 67-90.

UN (2005), Millennium Project 2005: Innovation: Applying Knowledge in Development, London: Earthscan.

UN/ECLAC (2010), Time for Equality, Closing Gaps, Opening Trails, Paper presented at the 33rd session of ECLAC, Brasilia, Brazil, 30 May to 1 June, Santiago, Chile: Economic Commission for Latin America and the Caribbean.

Vasen, F. (2015), 'Is "Responsible Research and Innovation" an Appropriate Framework for STI Policy in Latin America?', Paper presented at the Fourth International MVI Conference 'Responsible Innovation 2015: A European Agenda?', Netherlands Organisation for Scientific Research, The Hague, the Netherlands, 24-25 August.

Viotti, E.B. (2002), 'National Learning Systems - a New Approach on Technological Change in Late Industrializing Economies and Evidences from the Cases of Brazil and South Korea', Technological Forecasting and Social Change, 69 (7), 653-680.

Woolthuis, R.K., M. Lankhuizen and V. Gilsing (2005), 'A System Failure Framework for Innovation Policy Design', Technovation, 25 (6), 609-619.

World Bank (2010), Innovation Policy: A Guide for Developing Countries, Washington, DC: World Bank. 